\title{
異なる型の運動を含む両義的仮現運動の知覚
}

\author{
千田明, 市原茂
}

(首都大学東京人文科学研究科)

\section{Perception of bistable correspondence matching including different types of motion}

\author{
Akira CHIDA, Shigeru IchIHARA \\ Graduate School of Humanities, Tokyo Metropolitan University
}

\begin{abstract}
The present study investigated the percepts of bistable apparent motion in the conditions that the stimulus could induce translation-or rotation-motion. We used the Ternus display that can produce the bistable percepts of group motion and element motion. In experiment 1 , correspondence matching between central elements across frames in a Ternus display yields the percept of rotation. According to the one-to-one correspondence principle, though the percept of rotation for central elements should not be seen when group motion is perceived, group motion and rotation were perceived simultaneously in the ISI0ms condition. This percept in violation of the one-to-one correspondence was not produced by the stimuli consisting of the same type of motions (experiment 2). These results suggest that the correspondence matching yielding rotation may differ in the maintenance of element identity from the correspondence yielding translation (phenomenal identities accorded to the correspondence in translation), and that the entire stimulus percepts appear as an integrated form of those different levels of perceptual processing.
\end{abstract}

(Received 21 May, Accepted 11 August 2009)

Keywords: bistable apparent motion (両義的仮現運動), one-to-one correspondence (1 対 1 対応), types of motion (運動の型), phenomenal identity（現象的同一性）

\section{1.はじめに}

仮現運動とは，2つの刺激が異なる時点で異なる位 置に提示されたときに 2 つの刺激の間になめらかな運 動が知覚される現象である。仮現運動において, 最初 の時点のどの対象が次の時点のどの対象と対応するか (同一であるか) という問題は対応問題 (correspondence problem) とよばれる (Ullman, 1979).

対応問題が存在する刺激として両義的仮現運動（bistable apparent motion）がある.これは, 各時点で 提示される対象 (要素) が複数かつ同数であるために 複数の対応可能性が存在する刺激である．両義的仮現 運動の対応問題を解き一義的な知覚を実現するための 制約条件の一つとして, ある時点の一つの要素は次の
時点の唯一つの要素と対応づけられるという 1 対 1 対 応が仮定されている（Ullman, 1978；1979；Dawson, 1991).

Fig. 1 は Ternus 刺激（Ternus，1938）とよばれる 両義的仮現運動刺激である. Ternus刺激ではグルー プモーションとエレメントモーションのいずれかが知 覚される.グループモーションはすべての要素が一体 となって移動する (Fig. 1 (b))。エレメントモーショ ンは同一位置に提示される要素 (中央要素) は静止し, 端の要素のみが逆の端に移動する（Fig. 1 (c)). 一般 に, 短いISI (inter stimulus interval) ではエレメン トモーションが, 長いISI ではグループモーションが 知覚される (Pantle \& Picciano, 1976 ; Petersik, 1989). 
(a)

\section{frame 1 a}

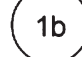

frame 2
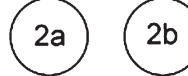

(b)
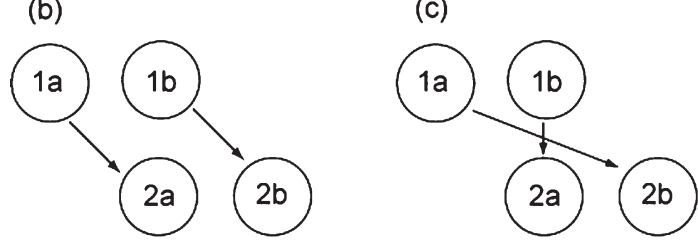

Fig. 1 (a) Illustration of Ternus display. Elements of $1 \mathrm{~b}$ and $2 \mathrm{a}$ are 'central elements'. These are presented at same location across frames. Correspondence of elements for group motion (b) and element motion (c).

Dawson（1991）は 1 対 1 対応を含む 3 つの制約条 件に基づいた対応問題解決モデルを提唱している。 し かし，Dawson（1991）のモデルや従来の両義的仮現 運動の多くは，どの対応づけがなされても知覚される 運動は並進運動のみであった。そのため形態や方位の 変化のような位置が変化しない運動が対応問題にどの ような影響を与えるかは明らかではない。そこで本研 究では, Ternus 刺激が異なる型の運動間の競合を含 んでいても 1 対 1 対応が成立するかを検討する.

Ternus 刺激において中央要素間に方位変化（回転） があっても (Fig. 2)，1対 1 対応に従えば，グループ モーションが知覚される場合は中央要素間は対応づけ られず回転は知覚されない. 反対にエレメントモー ションが知覚される場合には中央要素同士が対応づけ られ回転が知覚されるはずである。しかし，グループ モーションが知覚され，かつ中央要素の方位変化も知 覚される場合，それは 1 対 1 対応と矛盾していること になる。

\section{2. 実験 1}

\section{2-1. 方法}

実験参加者：正常な視力または矯正視力を有する大 学院生 5 名が実験に参加した.

装置：刺激の提示および反応の記録には，パーソナ ル・コンピュータ（GATEWAY 2000）と視覚実験用 のビデオカードであるVSG 2/3 (Cambridge Re-

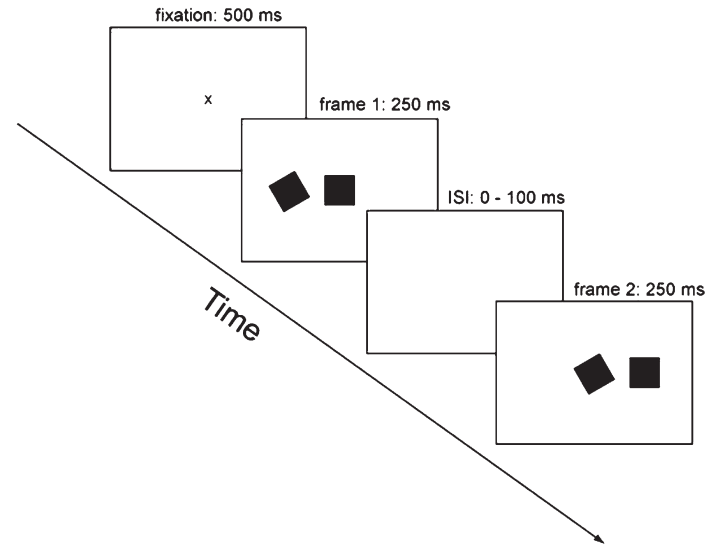

Fig. 2 Sequence of events and stimulus array of experiment 1 . Upstanding square in framel and rotation square in frame 2 are central elements. ISI (inter stimulus interval) is inserted between frames.

search Systems）を使用し，刺激画像はCRT モニ ター（SONY Multiscan 17se II）に提示した。モニ ターのリフレッシュレートは $100 \mathrm{~Hz}$ に設定した。

刺激：刺激に含まれる要素は正立した正方形とそれ を $30^{\circ}$ 回転させた図形である (Fig. 2)。図形は黒色 (輝度 $\left.2 \mathrm{~cd} / \mathrm{m}^{2}\right)$ で大きさが視角 $1.43^{\circ} \times 1.43^{\circ}$ ，背景は 白色 (輝度 $\left.90 \mathrm{~cd} / \mathrm{m}^{2}\right)$, 観察距離は $70 \mathrm{~cm}$ であった. 同一フレームの要素間の距離は視角 $2.87^{\circ}$ であり，第 一フレームの正立図形と第二フレームの回転図形は中 心が同じ位置に提示された。

手続き：図形条件として，回転図形を含む刺激を回 転条件, 正立図形のみの刺激をノーマル条件とした。 Fig. 2 に示すように注視点は $500 \mathrm{~ms}$ ，刺激画像は $250 \mathrm{~ms}$ 提示された。回転条件，ノーマル条件ともに ISI 7 条件（0，10，20，40，60，80，100ms）を設定 した。なお，刺激提示中に注視点は消失するが，その 位置を注視し続けるように実験参加者に教示した。

また，第 1 フレームで 1 つの正立図形を提示し，第 2 フレームで同じ位置に 1 つの回転図形を提示する単 一要素提示を, ISI 3 条件 $(0,40,100 \mathrm{~ms})$ について 実施した。 17 条件をランダム順に提示し，それを 20 回繰り返した。なお，各条件 20 回の繰り返しのうち 10 回は左方向への運動, 10 回は右方向への運動であ り, 回転図形の回転方向は並進運動と逆方向であった

Fig. 2 を 1 サイクルとし，1 試行につき 3 サイクル 提示した。実験参加者は刺激を観察後に，まずグルー プモーションとエレメントモーションのどちらが知覚 
(a)

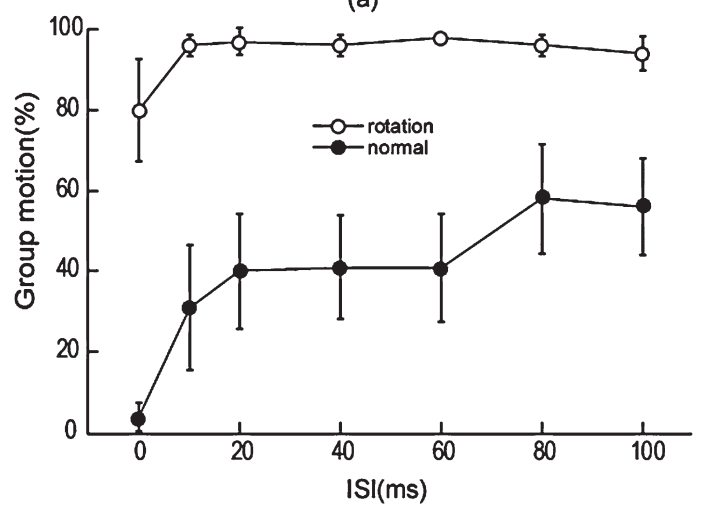

(b)

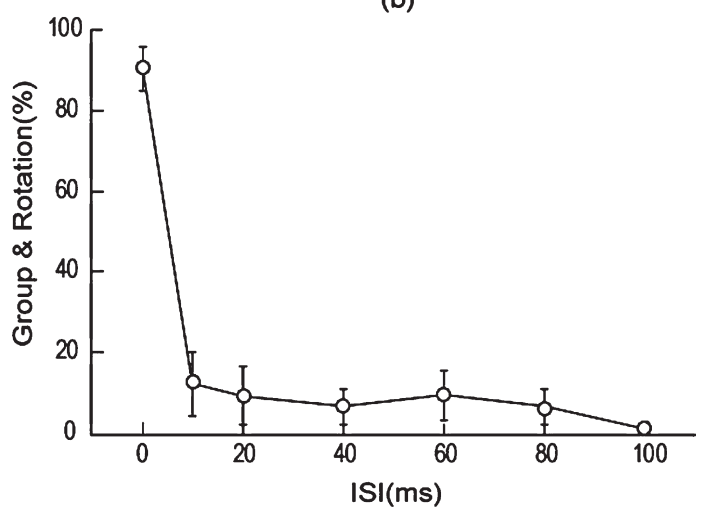

Fig. 3 Results of experiment 1. (a) Percent of group motion for each ISI. Open circles are rotation condition, and filled circles are normal condition. (b) Percent of rotation when group motion was perceived in rotation condition. Error bars indicate the standard error of means.

されたかを回答し，次に中央要素の回転が知覚された かどうかを回答した。単一要素提示では回転が知覚さ れたかどうかのみを回答した。

\section{2-2. 結果}

各 ISI 条件および各図形条件においてグループモー ションが知覚された割合を算出した (Fig. 3(a)). 2 要因分散分析を行ったところ, 眓形条件, ISI 条件と もに主効果が有意であった 俔形 $[F(1,4)=26.661$, $p<.01]$, ISI $[\mathrm{F}(6,24)=17.136, p<.01]\}$. 両者の 交互作用は認められなかった $[\mathrm{F}(6,24)=3.403$, n. s.]. 本研究で重要なのは, 回転条件においてグループ モーションが知覚された試行のうち中央要素の回転が 知覚された試行の割合である。この結果をみると (Fig. 3 (b)), ISI 0ms においてのみ高い割合で中央
要素の回転が知覚され $(90 \%)$, その他の ISI 条件で はほとんど中央要素の回転は知覚されていない（12\% 以下).これは, ISI 0msでは 1 対 1 対応と矛盾する 知覚が生じ, ISI が $10 \mathrm{~ms}$ 以上挿入された場合には 1 対 1 対応に従った知覚が生じていることを示している.

なお，ノーマル条件で回転運動が知覚された試行は なく, 単一要素提示ではすべての試行で回転運動が知 覚された。

\section{2-3. 考察}

回転条件において高い割合でグループモーションが 知覚されたのは, 眓形の方位が対応づけの手がかりと なったためであろう（Green, 1986 ; Schechter et al., 1988). しかし, このようなグループモーションへの バイアスが生じる条件下において, 中央要素の回転が 知覚されている. 1 対 1 対応に従えば, 中央要素の回 転が知覚された場合にそれは位置を変えずその場で回 転しているはずである。しかし, 同時にグループモー ションが知覚されていることから, 中央要素は横に並 進運動しているはずである. また, 第 2 フレームの中 央要素は, グループモーションでは隣り合う要素が並 進運動したものに対応する。したがって，グループ モーションによる対応と, 回転による対応は矛盾して いることになる.

この矛盾する知覚は ISI が $0 \mathrm{~ms}$ の条件でのみ多く 観察され, ISIが $10 \mathrm{~ms}$ 以上になれば回転は知覚され ずにグループモーションのみが知覚されている。これ は並進運動と回転の性質の違いによると考えられる. 提示される要素が各フレームで 1 つずつ（単一要素提 示）ならば, 対応が競合する要素がないため ISI が 100ms であっても回転が知覚できる。 しかし, 並進 運動と回転が競合する刺激事態ではそれぞれの対応の 強さによって知覚が決定される.

ISI が $10 \mathrm{~ms}$ でも挿入された場合, すべての要素が 一旦その場から消失する，位置の変化を伴わない回転 の場合, その要素は連続してその場に存在した方がよ り対応が強いと思われる. それに対し並進運動はISI や移動距離に関して許容範囲が比較的広い. そのため ISI が $10 \mathrm{~ms}$ 以上では, 同じ位置での回転を伴う対応 づけよりも並進運動を伴う対応づけが強くなり回転が 知覚されなくなったと考えられる.

\section{3. 実験 2}

実験 1 の結果から, 1 対 1 対応に従わない知覚は運 動の型の違いによることが示唆された．実験 2 ではグ 
frame 1

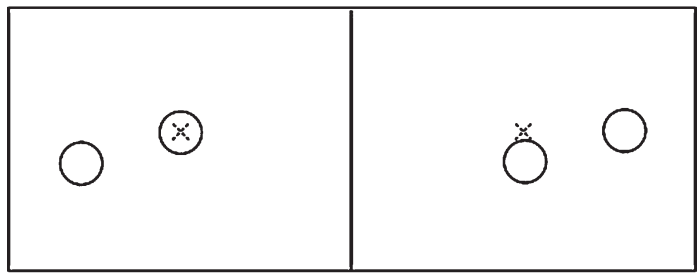

Fig. 4 Stimulus array of experiment 2. The fixation point (dashed line) disappears when elements are presented. Elements are black circles in actual stimulus. Central elements differ in positions of vertical direction across frames.

ループモーションと中央要素に同じ型の運動（並進運 動）を用いる. 同じ型の運動でも 1 対 1 対応と矛盾す る知覚が生じれば, 実験 1 の結果は運動の型の違いに よるものではなく，連続して同じ，または隣接した位 置に提示される要素間に対する強制的な運動知覚のた めと考えられる。なお, 一般の Ternus 刺激では中央 要素の位置変化がないため, 実験 2 の刺激は Ternus 刺激ではないが, 実験 1 との比較のためグループモー ション，エレメントモーションという呼称を使用する.

\section{3-1. 方法}

実験参加者：正常な視力および矯正視力を有する大 学院生 5 名が実験に参加した. そのうち 2 名は実験 1 にも参加した。

装置 : 実験 1 と同様の装置を用いた.

刺激 : Fig. 4 に示すように, 実験 2 では並進運動の みを問題とするため, 正方形の辺のような直線的手が かりにより運動方向が決定されるのを防ぐため要素を 円形とした。中央要素はフレーム間で垂直方向の位置 が異なる，要素や背景の輝度，および要素間の水平方 向距離は実験 1 と同様であった. 要素の大きさは $1.6^{\circ}$ $\times 1.6^{\circ}$ で，これは実験 1 で用いられた正方形とほぼ等 しい面積である.

手続き：ISI 7 条件 $(0,10,20,40,60,80,100$ $\mathrm{ms}$ ) ×垂直距離 4 条件（視角 $0.2^{\circ}, 0.4^{\circ}, 0.8^{\circ}, 1.6^{\circ}$ ）の 計 28 条件を設定した。 ここで, 垂直距離は中央要素 の中心間距離である. したがって，この值が大きいほ ど中央要素の垂直運動距離も大きくなる. 28 条件を ランダム順に提示し, それを 14 回繰り返した。 なお, 各条件 14 回の繰り返しのうち 7 回は左方向への運動, 7 回は右方向への運動であった. 刺激提示時間および サイクル数は実験 1 と同様であった. (a)

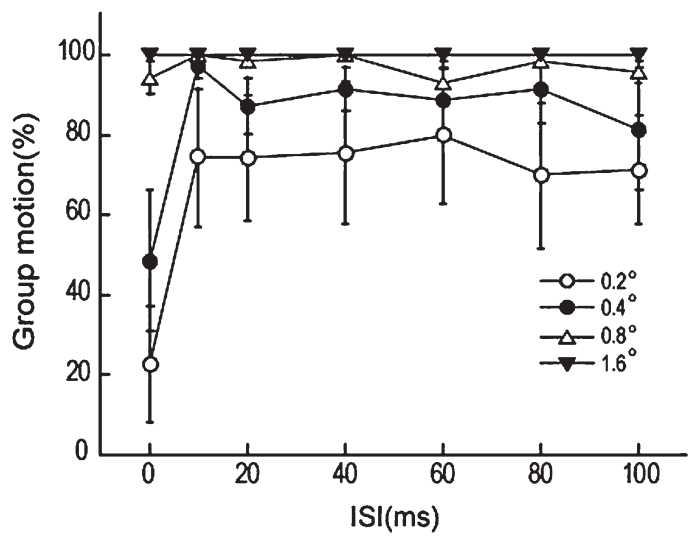

(b)

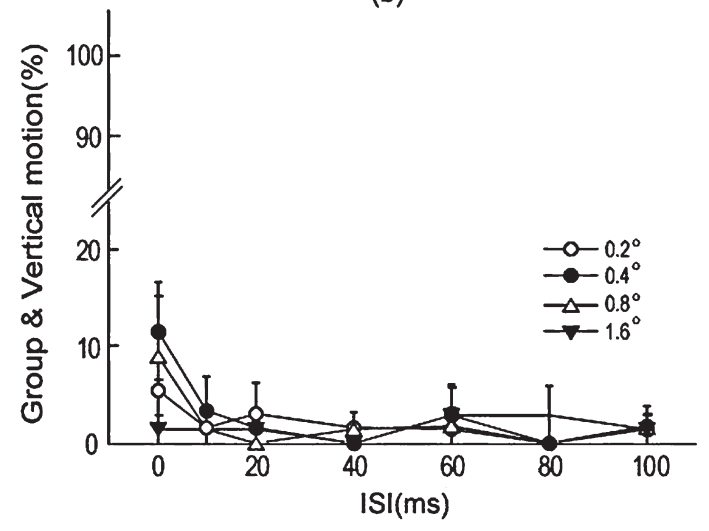

Fig. 5 Results of experiment 2. (a) Percent of group motion for each ISI. Open circles are $0.2^{\circ}$, filled circles are $0.4^{\circ}$, open triangles are $0.8^{\circ}$ and filled inverse triangles are $1.6^{\circ}$ condition. (b) Percent of vertical motion when group motion was perceived. Error bars indicate the standard error of means.

実験参加者は刺激を観察後に，まずグループモー ションとエレメントモーションのいずれが知覚された かを回答し, 次に中央要素の垂直運動が知覚されたか を回答した。

\section{3-2. 結果}

各 ISI 条件および各垂直距離条件においてグループ モーションが知覚された割合を算出した（Fig. 5 (a)) 2 要因分散分析を行ったところ, ISI の主効果が有意 であったが垂直距離の主効果は有意傾向であった ISI : $\mathrm{F}(6,24)=11.143, p<.05$, 垂直距離 : $\mathrm{F}(3,12)$ $=4.665, p<.1\}$. 両者の交互作用が有意であった $(\mathrm{F}(18,72)=4.744, p<.05)$ ため, 各 ISI 条件におけ 
る垂直距離の単純主効果の検定を行ったところ, ISI $0 \mathrm{~ms}$ 条件でのみ有意であった。各垂直距離条件にお ける ISI の単純主効果は, $0.2^{\circ}, 0.4^{\circ}$ 条件で有意であっ た.

ISI が 0ms ではエレメントモーションが知覚されや すいが, 垂直距離が大きくなるほどグループモーショ ンが知覚されている。しかし，この垂直距離の効果は ISI が $10 \mathrm{~ms}$ 以上では見られなかった。これは，通常 の Ternus 刺激では ISI が大きいほどグループモー ションが知覚されやすくなることから, ISI が $10 \mathrm{~ms}$ 以上では全体的にグループモーションへのバイアスが 生じ, 垂直距離の効果が表れにくいと考えられる。 ま た, 小さい垂直距離条件 $\left(0.2^{\circ}, 0.4^{\circ}\right)$ では ISI の単純 主効果がみられたが, ISI が $10 \mathrm{~ms}$ 以上ではグループ モーションの生起率がほぼ一定であることから，これ は ISI 0msでの垂直距離の効果を反映していると考元 られる。

実験 2 において最も重要なのは, グループモーショ ンが知覚された試行のうち中央要素の垂直運動が知覚 された割合である (Fig. 5 (b))。結果はすべての ISI 条件㧍よび垂直距離条件でグループモーションと垂直 運動が同時に知覚された割合は $11 \%$ 以下となった。 ISI $0 \mathrm{~ms}$ での垂直距離 $0.2^{\circ}$ 条件ではグループモーショ ンの生起率自体が小さいが, それが $49 \%$ の $0.4^{\circ}$ 条件

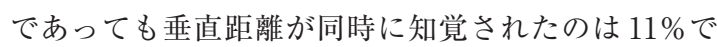
あった。

\section{3-3. 考察}

一般に仮現運動の対応づけでは，全運動量が最小に なるように知覚される (Ullman, $1978 ； 1979)$. 要素 の移動距離の総和を全運動量とすると, 実験 2 の刺激 でエレメントモーションが知覚される場合, 中央要素 の垂直距離が大きいほど全運動量は大きい，反対にグ ループモーションが知覚される場合, 要素は横への移 動のみであり, 全運動量は一定である，そのため，垂 直距離が大きいほどグループモーションの生起率が大 きくなったと考えられる.

実験 1 ではグループモーションへのバイアスがか かった条件下でも中央要素の回転が知覚された。しか し実験 2 では, グループモーションと垂直運動が同時 に知覚される割合はどの条件でも低かった，また，エ レメントモーションが知覚された試行のうち $68 \%$ は 垂直運動が知覚された。これは，1対 1 対応に従った 知覚であり実験 1 とは異なる結果である。したがって, 実験 1 での 1 対 1 対応と矛盾する知覚は運動の型の違
いによると考えられる．

\section{4. 総合考察}

本研究では, 並進運動と回転という異なる型の運動 が競合する両義的仮現運動の対応問題を検討した。そ の結果, 両者が競合する刺激では 1 対 1 対応に従わな い知覚が生じたが, 同じ型の運動では整合的な知覚が 生じたことから, 1 対 1 対応と矛盾する知覚は運動の 型の違いによることが示唆された.

実験 1 に扔ける余分な回転の知覚は, 正方形の角の ような特徵点を考えれば対応問題における全運動量最 小の原則にも反する。しかし, 図形全体の並進運動の みを考えれば回転が知覚されるかに関わらず全運動量 は同じである。また, 実験 1 の実験参加者の言語報告 によれば，グループモーションと回転が知覚された場 合には端の要素が中央要素の位置まで移動した後に回 転が知覚されている。つまり，1 対 1 対応を仮定した 客観的な同一性とは矛盾するが, 個々の要素の現象的 同一性は維持されていることになる. したがって, 同 一性を維持するという意味での対応づけでは並進運動 とその運動量のみが問題となり, 最終的な知覚内容に おいて回転の情報が並進運動での要素の同一性と矛盾 しない形で付与されるという可能性が考えられる.

その場合, 両者がどのような知覚過程に媒介されて いるのかが問題となる. それには二つの可能性が考え られる.一つは知覚的処理水準の違いである. ScottSamuel \& Hess (2001) は, Ternus 刺激の知覚は高 次の特徵追跡的処理にのみ媒介されるとしている。 ま た, Dawson（1991）のモデルは運動検出そのもので はなく同一性維持のための高次モデルである。これら の研究で扱われている運動は並進運動のみであること から, 位置変化を伴う対応づけは高次過程, 位置変化 を伴わない回転などの知覚は低次過程に主に媒介され ている可能性が考えられる.

もう一つは過渡型/持続型チャンネルという性質の 異なる視覚処理経路である。過渡型チャンネルは刺激 の on/offに反応し, 主に運動知覚に関わるとされ, 持続型チャンネルは主に形の知覚に関わると考えられ ている. 実験 1 において ISI が $10 \mathrm{~ms}$ 以上の場合は, 中央要素の位置にも on/off が生じ過渡型チャンネル が反応することで中央要素の位置変化を検出し回転が 知覚されにくくなる. ISI が $0 \mathrm{~ms}$ の場合は, 中央要素 の位置に on/off が生じないため回転が知覚されやす くなるということが考えられる. 仮に回転の知覚が持 
続型チャンネルに媒介されているとすれば，過渡型 チャンネルとは異なる処理過程であるため実験 1 の ISI $0 \mathrm{~ms}$ では回転の知覚が抑制されず, 実験 2 や実験 1 の ISI $10 \mathrm{~ms}$ 以上では全ての要素が過渡型チャンネ ルに媒介されるため回転が抑制されやすいと考えられ る. しかし，持続型チャンネルが方位の変化から回転 を検出しているかどうかは明らかではない. また，こ れらの異なる処理過程がどのレベルでどのように統合 され, 最終的な知覚内容として現れるのかも今後の研 究課題である.

\section{引用文献}

Dawson, M. R. W. (1991) The how and why of what went where in apparent motion : Modeling solutions to the motion correspondence problem. Psychological Review, 98, 569-603.

Green, M. (1986) What determines correspondence strength in apparent motion? Vision Research, 26, 599-607.

Pantle, A., \& Picciano, L. (1976) A multistable move- ment display : Evidence for two separate motion systems in human vision. Science, 193, 500-502

Petersik, J. T. (1989) Two motion distinction in apparent motion. Psychological Bulletin, 106, 107-127. Scott-Samuel, N. E., \& Hess, R. F. (2001) What does the Ternus display tell us about motion processing in human vision? Perception, 30, 1179-1188.

Shechter, S., Hochstein, S., \& Hillman, P. (1988) Shape similarity and distance disparity as apparent motion correspondence cue. Vision Research, 28, 1013-1021.

Ternus, J. (1926) The problem of phenomenal identity. In A Sourcebook of Gestalt Psychology, Routledge and Kegan Paul, London, 149-160.

Ullman, S. (1978) Two dimensionality of the correspondence process in apparent motion. Perception, 7, 683-693.

Ullman, S. (1979) The Interpretation of Visual Motion, MIT Press, Cambridge, Mass. 